\title{
Mating system in a clonal Douglas fir (Pseudotsuga menziesii (Mirb) Franco) seed orchard. I. Gene diversity and structure
}

\author{
D Prat *, T Caquelard
}

Laboratoire INRA-ENGREF de sciences forestières, 14, rue Girardet, 54042 Nancy cedex, France

(Received 15 February 1994; accepted 15 July 1994)

\begin{abstract}
Summary - The clonal seed orchard studied consisted of 60 clones phenotypically selected in Douglas fir stands planted in France during the first half of the twentieth century. The genotype of every clone was characterised using isozyme techniques. Seven enzyme systems were studied, 1 was monomorphic, and 9 polymorphic loci were analysed. Seven loci (from 5 enzyme systems) were sufficient for genetic identification of each clone. Rare alleles were noticed at 7 of the 9 polymorphic loci studied. Three rare alleles were used to assess the selfing rate of individual ramets, but 2 of them might have led to erroneous results because of their selective disadvantage. The individual selfing rates, assessed from the rare allele transmission by pollen, were low $(2-5 \%)$. The gene diversity in pollen received by a single ramet was not representative of that of the seed orchard, and was not similar to that expected according to the seed orchard composition. Commercial seed crop exhibited a higher fixation index than that related to selfing rate and a significant deviation from the allelic frequencies expected in the orchard.
\end{abstract}

isozyme / mating system / rare allele / selfing / Pseudotsuga menziesii = Douglas fir

Résumé - Régime de reproduction dans un verger à graines de Douglas (Pseudotsuga menziesii (Mirb) Franco). I. Structure et variabilité génétique. Le verger à graines étudié est constitué de 60 clones sélectionnés phénotypiquement dans des peuplements français de Douglas plantés au cours de la première moitié du xxe siècle. Chaque clone a été caractérisé par son profil enzymatique. Sept systèmes enzymatiques ont été révélés, un seul s'est montré monomorphe, 9 locus polymorphes ont été analysés. Sept locus (cinq systèmes enzymatiques) étaient suffisants pour lidentification de tous les clones. Sept des 9 locus polymorphes analysés présentaient des allèles rares (portés par un seul clone). Trois allèles rares ont été utilisés pour estimer le taux d'autofécondation individuel de 3 ramets, mais 2 d'entre eux pouvaient fournir des valeurs erronées du fait de leur désavantage sélectif. Les taux individuels d'autofécondation observés sont faibles (2 à $5 \%$ ). La variabilité génétique du nuage polli-

*Present address: INRA, station d'amélioration des arbres forestiers, Ardon, 45160 Olivet, France 
nique reçu par un ramet n'est pas représentative du verger à graines. La semence commerciale du verger montre un indice de fixation supérieur à celui dû à ces taux d'autofécondation, et de plus des écarts significatifs ont été notés dans les fréquences alléliques observées par rapport à celles attendues dans le verger compte tenu de sa composition.

allèle rare / autofécondation / isoenzyme /Pseudotsuga menziesii = Douglas / régime de reproduction

\section{INTRODUCTION}

Douglas fir (Pseudotsuga menziesii (Mirb) Franco) was introduced into Europe during the last century. It is favoured by foresters for its growth and high wood quality and has recently become the main species for afforestation in France (Bastien et al, 1986). Selection of adapted provenances in natural range and in exotic plantations was the first step of the French genetic improvement programme (Christophe and Birot, 1983; Bastien et al, 1986; Bastien and RomanAmat, 1990). Seed orchards were established with plus trees selected in artificial stands or with clones selected from the best natural or artificial provenances on the basis of provenance tests in France. Seed orchards were planted several kilometres from the nearest plantation to avoid pollen contamination.

The genetic quality of seed produced in a seed orchard is greatly influenced by the mating system. Self-fertilisation may substantially reduce genetic gains (Sorensen, 1982; Sorensen and White, 1988). Various studies of clonal Douglas fir seed orchards, carried out in the natural range of the species, have generally revealed a low selfing level (Omi and Adams, 1986; Erickson and Adams, 1990). However significant levels of contamination by exogenous pollen occur because of the proximity of natural populations (El-Kassaby and Ritland, 1986; Fast et al, 1986; Adams and Birkes, 1991). The individual tree selfing rate is generally low (Erickson and Adams, 1990; Prat and Caquelard, 1991). The mating system, often restricted in models to selfing and cross- pollination, is influenced by floral phenology and pollination distance (Erickson and Adams, 1989) as well as other factors such as pollen availability or fecundity, and individual tree genetic load.

The purpose of this paper is to describe the mating system, and especially to estimate the rate of selfing (determined on a few individual ramets) during a year of heavy seed production. The consequence of the mating system on the commercial seed crop was determined. Isozyme genotypes of the clones in the orchard were determined and used for the analyses. In addition, the results of this investigation allowed for the comparison of genetic structure and diversity of clones and seed crop.

\section{MATERIALS AND METHODS}

\section{Plant material and seed orchard design}

The Bout-24 clonal Douglas fir seed orchard, located in Gros Bois National Forest, near Moulins in France $\left(3^{\circ} 02^{\prime} \mathrm{E}, 46^{\circ} 31^{\prime} \mathrm{N}\right)$ was planted in 1966. It is surrounded by other seed orchards (Pinus pinaster, $P$ sylvestris, Larix decidua) and hardwood forest (mainly Quercus). The nearest Douglas fir stand consists of a seed orchard established 1 year later, about $1 \mathrm{~km}$ to the east. Bout-24 seed orchard is composed of 60 phenotypically selected clones from 11 Douglas fir French stands (2-10 per stand) of unknown provenance. One ramet of each clone was planted at random in each of the 20 blocks of the seed orchard. The distance between grafted ramets was $5 \mathrm{~m}$ between and within rows. Graft incompatibility appeared rapidly; about half of the trees were dead at the time of the present study. 
Seeds were collected in 1987 . The seed production in the Bout seed orchard that year was the first to be significant (about $45 \mathrm{~kg}$ of seeds per hectare). Floral phenology and abundance were recorded for several years in some blocks of the Bout orchard but these 2 traits showed a great variability among years and these parameters cannot be used. In 1987 a large part of the seed orchard was observed during the particularly short flowering period, limited to about $10 \mathrm{~d}$ in that year. As flowering was very synchronous for almost all clones, it was not taken into account. Seeds were collected separately on all the ramets present in 4 blocks (ie 1 to 4 ramets per clone according to the survival rate) and on some ramets in additional blocks so as to have seeds from every clone. Thirty-nine clones were represented in the collections by a single ramet, 21 clones were represented by $2-4$ ramets. Seeds and buds from all sampled ramets of these 21 clones were analysed electrophoretically to verify the genetic integrity of these clones. A commercial seed crop collected as a bulk seed lot in the same year on the ramets producing numerous cones was also available and analysed.

\section{Laboratory methods}

Megagametophytes and embryos of seeds soaked in water for $2 \mathrm{~d}$ were dissected and separately crushed in $30 \mu \mathrm{l}$ Tris- $\mathrm{HCl}$ buffer $(\mathrm{pH} 7.4,10$ $\mathrm{mM}$ ) supplemented with $\mathrm{KCl} 25 \mathrm{mM}$ and sucrose $29 \mathrm{mM}$. Enzymes were also extracted from some dormant buds according to Adams et al (1990). Electrophoresis was carried out in polyacrylamide gels with a continuous buffer system (Tris $90 \mathrm{mM}$, $\mathrm{H}_{3} \mathrm{BO}_{3} 90 \mathrm{mM}$, EDTA $2.5 \mathrm{mM}$, pH 8.4) for $3.5 \mathrm{~h}$ under $12 \mathrm{~V} / \mathrm{cm}$. Seven enzyme systems were assayed according to the methods described by Conkle et al (1982): $\alpha$-esterase ( $\alpha$-EST, E.C 3.1.1.1), glutamate oxaloacetate transaminase (GOT, E.C 2.6.1.1), glucose-6-phosphate dehydrogenase (G6PDH, E.C 1.1.1.49), glutamate dehydrogenase (GDH, E.C 1.4.1.2), leucineamino peptidase (LAP, E.C 3.4.11.1), malate dehydrogenase (MDH, E.C 1.1.1.37) and 6-phosphogluconate dehydrogenase (6PGD, E.C 1.1.1.44). Mendelian inheritance of isozyme patterns was controlled by segregation in mega gametophytes and was identical to that described by Adams et al (1990). The loci analysed were expressed in both megagametophytes and embryos.

\section{Genetic analysis of mating system}

Genetic analyses were carried out using isozyme markers. Megagametophytes of 10 seeds per tree were analysed separately to assess mother tree genotypes. Seed orchard clones and commercial seedlots were analysed for levels of allelic polymorphism and fixation indices. The genetic structure of clones, distributed in subpopulations corresponding to the location of their ortets in French stands, was also studied by the F-statistics of Wright (1965).

Rare alleles (borne by individual clones) were used to detect every self-pollination without significant contamination. The chosen ramets were at least $40 \mathrm{~m}$ from any other ramets of the same clone. It was assumed that this degree of isolation essentially eliminates crosses between ramets of the same clone, since pollen dispersal from individual ramets appears to be extremely limited beyond $30-35 \mathrm{~m}$ in Douglas fir seed orchards (Erickson and Adams, 1989). Segregation of rare alleles among pollen gametes in heterozygous mother trees was assumed to be 1:1.

Embryos and megagametophytes of about 500 seeds per tree were separately analysed to determine the selfing rate from the genotypes of male gametes. Selfed and outcrossed embryos were under binomial distribution; confidence intervals were determined according to binomial law. The possible disadvantage of the rare allele was assessed by the statistical significance ( $\chi^{2}$ test) of the deviation of the observed from the expected segregation (1:1) in the megagametophytes of heterozygous trees. The disadvantage might be different in male and female transmission of rare allele but it cannot be tested in male transmission. In that approach a single locus was considered. When pollen from the studied ramet could be identified according to its complete genotype (with and without consideration of rare allele) a multilocus estimation of selfing rate was carried out.

The mixed-mating model was also applied (Ritland and El-Kassaby, 1985; Ritland, 1986) for estimation of individual outcrossing rate.

\section{Commercial seed crop}

In a well-managed seed orchard, the seed crop should be produced under panmixia and represent the same genetic diversity as the mother 
trees. The genetic structure of the commercial seed crop was compared with that expected under panmixia. Seeds of the commercial crop were only collected on a sample of tress (all those bearing enough cones), which consisted of ramets of 50 out of the 60 clones planted in the orchard. As those ramets did not represent complete allelic diversity of the seed orchard only genetic variation of the pollen was studied. The male gametes derived from the embryo and megagametophyte genotypes were produced by more than the collected trees and should be representative of the genetic diversity of the seed orchard. Four hundred seed of the commercial seedlot were analysed.

Two independent parameters were recorded on each clone for weighting their reproductive efficiency and thus to explain possible discrepancies $\left(\chi^{2}\right.$ test) between expected and observed allelic frequencies: (1) actual number of ramets; and (2) male contribution (product of the frequency of flowering ramets and abundance of male catkins noted in 3 classes of abundance, low, intermediate, and high). Parameters were tested alone and in combination.

\section{RESULTS}

\section{Genetic diversity and structure of the seed orchard}

Six out of the 7 enzymatic systems showed polymorphic loci, only GDH was monomorphic. Two loci in LAP, 3 loci in $\mathrm{MDH}$ and one locus in each of the other enzymatic systems were genetically analysed. Five loci ( $\alpha$-Est, G6pdh, Lap-1, Mdh-1 and Moh3) were moderately to highly polymorphic (table 1). The addition of 2 other less polymorphic loci (Mdh-2 and 6Pgdh) was sufficient for the genetic characterisation and individual identification of each clone in the orchard. Nine alleles unique to individual clones (rare alleles) were observed, all occurring in the heterozygous condition. Two of them were borne by the same clone (clone 64). Two rare alleles were null (inactive) alleles and were not easily detectable in heterozygous diploid material.
In 7 clones out of 21 , the ramets of the same clone did not show a single genotype; one or several new gentoypes were observed among a presumed clone. This heterogeneity resulted from the rootstocks which took the place of the scion after a graft rejection. Thus the 7 enzyme loci allowed the identification of the clones and some peculiar trees. Isozymes from buds collected from several ramets in the seed orchard confirmed the heterogeneity of the same presumed clones. The assessed genotype of the clone, the most frequent among ramets, was then considered in further analyses, which are described in this paper.

The clones planted in the seed orchard did not show any deviation of Hardy-Weinberg equilibrium ( $F_{\mathrm{IT}}=0.006$, considering the same number of ramets in each clone), but the negative $F_{I S}$ value $(-0.143)$ probably resulted from the selection for heterozygous clones in French stands (table II).

\section{Selfing rate and pollination}

The selfing rate was first deduced from the pollen transmission of rare alleles. Six clones bore active rare alleles (table I). Two clones were chosen for the study: clone 64 ( 2 ramets), because it bore 2 rare alleles; and clone 95 (1 ramet), because of possible identification of male gametes even in the absence of rare allele. Most of the other clones bearing rare alleles were not used because of the low number of seeds available even in 1987 or because of the short distance between flowering ramets. The same seed sample was analysed for the different enzyme systems. As every rare allele was heterozygous, the selfing rate was estimated as twice the frequency of pollen gametes with rare alleles.

In clone 64 ramets, a few pollen gametes were observed with the rare allele of Got-1 (table III); there was a significantly larger 
Table I. Allelic diversity observed in the clonal seed orchard.

Locus Number of alleles $\begin{gathered}\text { Frequency of the } \\ \text { most common allele }\end{gathered} \quad$ Rare allele Clone bearing rare allele

\begin{tabular}{|c|c|c|c|c|}
\hline$\alpha$-Est & 8 & 0.467 & $\begin{array}{l}\alpha-E s t_{0} \\
\alpha-E s t_{1}\end{array}$ & $\begin{array}{l}\text { null allele } \\
\text { fast allele }\end{array}$ \\
\hline G6pdh & 6 & 0.467 & $\begin{array}{l}G 6 p d h_{1} \\
G 6 p d h_{6}\end{array}$ & $\begin{array}{l}\text { fast allele } \\
\text { slow allele }\end{array}$ \\
\hline Got-1 & 2 & 0.992 & Got- $f_{1}$ & fast allele \\
\hline Lap-1 & 4 & 0.400 & & \\
\hline Lap-2 & 3 & 0.967 & Lap-2 $2_{3}$ & slow allele \\
\hline$M d h-1$ & 3 & 0.800 & $M d h-1_{1}$ & fast allele \\
\hline$M d h-2$ & 2 & 0.975 & & \\
\hline$M d h-3$ & 3 & 0.833 & $M d h-3_{1}$ & fast allele \\
\hline $6 P g d h$ & 3 & 0.908 & $6 P g d h_{0}$ & null allele \\
\hline
\end{tabular}

Table II. Genetic structure of the clonal seed orchard according to the French stands where clones were selected.

\begin{tabular}{lrr} 
Allele & \multicolumn{2}{c}{ F-statistic } \\
\cline { 2 - 3 } & \multicolumn{1}{c}{$F_{I S}$} & $F_{S T}$ \\
& & \\
& & \\
-Est & 0.001 & 0.151 \\
G6pdh & -0.208 & 0.189 \\
Got-1 & -0.067 & 0.057 \\
Lap-1 & -0.313 & 0.144 \\
Lap-2 & -0.132 & 0.092 \\
Mdh-1 & -0.058 & 0.059 \\
Mdh-2 & -0.114 & 0.079 \\
Mdh-3 & -0.029 & 0.035 \\
6Pgdh & -0.159 & 0.082 \\
Mean & -0.143 & 0.131
\end{tabular}

$F_{\mathrm{IS}}$ : structure within stand; $F_{\mathrm{ST}}$ : structure between stands.

number of pollen gametes for the rare allele of G6pdh. The same result was obtained in both ramets of clone 64 . Thus, the estimation of the selfing rate varied according to the locus analysed. No homozygous embryo for a rare allele was observed: only the analyses of both embryo and megagametophyte of the same seed allowed the detection of selfing. The segregation observed in the megagametophytes at the locus Got-1 showed a disadvantage for the rare allele (table IV). No such deviation was observed at the locus G6pdh. Both loci were genetically independent $\left(\chi^{2}=0.5\right)$ according to the 1040 gametes analysed. The rare allele of Got-1 was slightly selected against in female gametes. Deficiency of Got-1 rare allele would have to be much greater than indicated by megagametophyte segregation to account for the few observed pollen gametes with the rare allele. This rare allele was probably selected against in both male and female gametes. The best estimation of selfing rate might be obtained with the G6pdh locus, the average selfing rate of the 2 ramets of clone 64 being about $4.0 \%$. The selfing rate assessed from $G 6 p d h$ locus and from mixed mating model (G6pdh and Got-1 loci taken into account) were not significantly different (table III).

Segregation of the rare allele in the megagametophytes of clone 95 ramet showed a significant disadvantage (table IV). The estimation of the selfing rate by the rare allele or by a multilocus method gave the same value (table III). Seven loci were considered for the multilocus approach. All male gametes produced by clone 95 were 
Table III. Selfing rate (after pollen gametes with rare alleles and a multilocus analysis; sample size $=$ more than 400 seeds per ramet) of individual heterozygous ramets.

\begin{tabular}{|c|c|c|c|}
\hline Clone & Ramet & Locus & Selfing-rate (\%) a \\
\hline \multirow[t]{6}{*}{64} & 1 & G6pdh & $3.0 \pm 2.1$ \\
\hline & & Got-1 & $0.0 \pm 0.8$ \\
\hline & & Mixed-mating model & $2.0 \pm 3.8$ \\
\hline & 2 & G6pdh & $5.0 \pm 2.7$ \\
\hline & & Got-1 & $0.4 \pm 0.8$ \\
\hline & & Mixed-mating model & $6.0 \pm 1.9$ \\
\hline \multirow[t]{2}{*}{95} & 1 & $M d h-3$ & $2.3 \pm 1.4$ \\
\hline & & Multilocus & $2.3 \pm 1.7 b$ \\
\hline
\end{tabular}

a $5 \%$ confidence intervals; b larger confidence interval because of a reduced number of fully recorded pollen genotypes.

Table IV. Segregation in megagametophytes of trees heterozygous for rare alleles ( 1040 seeds of clone 64,431 seeds of clone 95$)$.

\section{Clone Rare allele Rare allele:common allele}

\begin{tabular}{|c|c|c|}
\hline 64 & $G 6 p d h_{6}$ & $0.50: 0.50$ \\
\hline & Got-1 1 & $0.45: 0.55$ \\
\hline 95 & $M a h-3_{1}$ & $0.45: 0.55$ \\
\hline
\end{tabular}

Significant distortion of segregation at the * 0.05 and ${ }^{\star *} 0.01$ levels.

thus uniquely identified even without the rare allele and all of them were taken into account. The disadvantage observed in the female transmission of the $M d h-3$ rare allele did not seem to exist in the male transmission since the multilocus and Mdh-3 estimates of the selfing rate were identical. The selfing rate of this ramet was $2.3 \%$.

Allelic frequencies of pollen were significantly different to those expected in the seed orchard (allele frequency of living ramets) for instance at the G6pdh locus (table V).
Table V. Allelic frequencies at the locus G6pdh of 518 effective pollen gametes received by ramet 2 of clone 64 (genotype $G 6 p d h_{2} / G 6 p d h_{6}$ ) and of seed orchard considering each living ramet.

Allele Pollen frequency $\begin{gathered}\text { Seed orchard } \\ \text { frequency }\end{gathered}$

$\begin{array}{lll}G 6 p d h_{1} & 0.014 & 0.009 \\ \text { G6pdh } & 0.504 & 0.456 \\ \text { G6pdh } & 0.343 & 0.428 \\ \text { G6pdh } & 0.104 & 0.058 \\ \text { G6pdh } & 0.010 & 0.040 \\ \text { G6pdh } & 0.025 & 0.009\end{array}$

Frequencies are significantly different even when the selfing rate of this ramet $(5 \%)$ is taken into account $\left(\chi^{2}=\right.$ 43.4 (significant at the 0.001 level) major contribution for $\mathrm{G} 6 p d h_{3}, \mathrm{G} 6 p d h_{4}$, and $\mathrm{G} 6 p d h_{5}$ alleles).

\section{Commercial seed crop}

The numbers of alleles per locus observed in the seed crop showed a few deviations from those observed in the mother trees at the same loci (table VI). Common alleles in the clones and in the commercial seedlot 


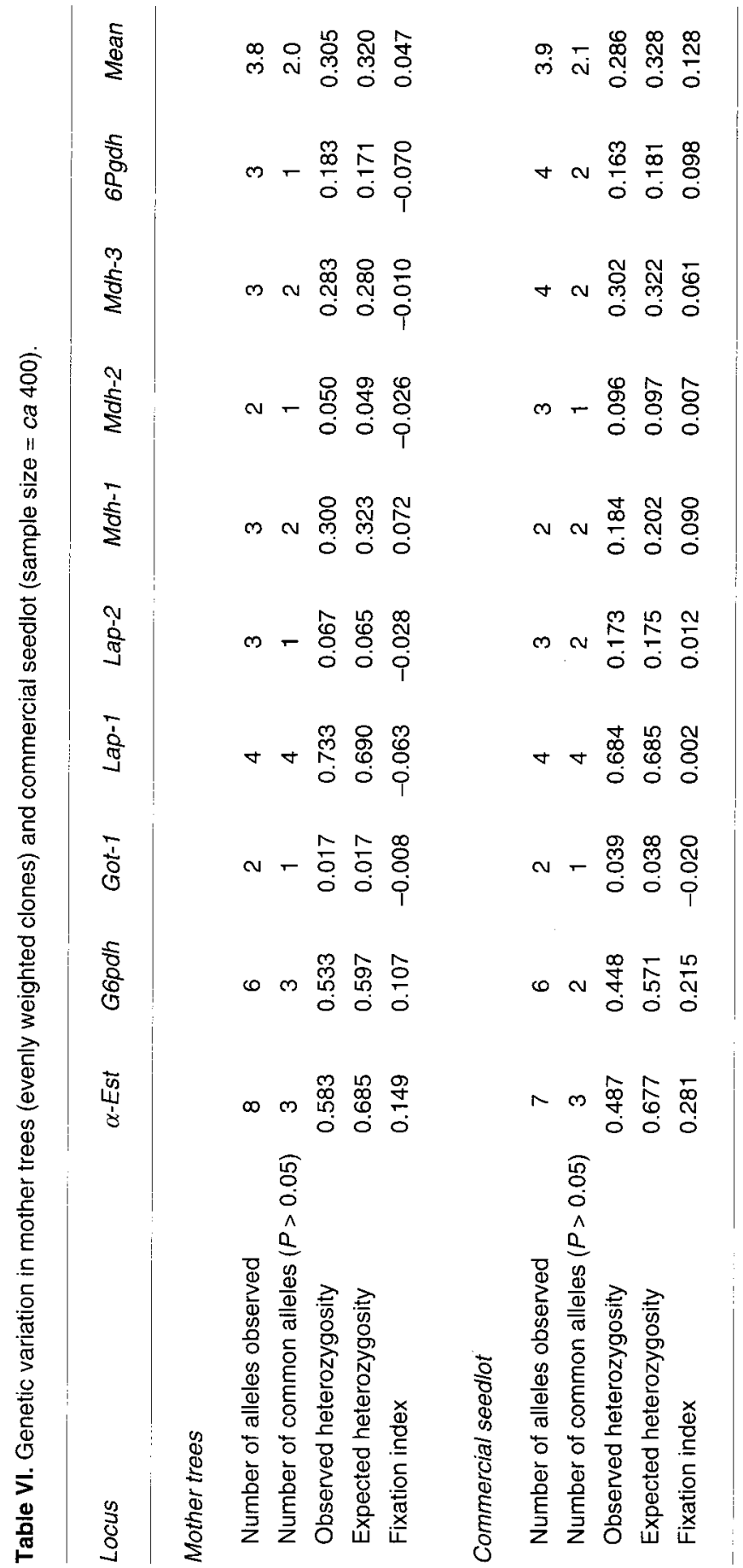


were the same except at the G6pdh locus. Some new alleles were observed at a low frequency; they certainly came from flowering rootstocks (or from mis-characterised clones when only 1 ramet was analysed). The average observed heterozygosity was lower in the offspring than in the clones (table VI). The higher value of fixation indices of offspring compared with that of mother trees was only partly explained by selfing.

The pollen allelic frequencies differed significantly from the expected composition assessed under random mating according to the clone genotypes for the 5 most polymorphic loci (table VII). When the number of living ramets of each clone was considered (instead of the same weighting for each clone), the expected values were improved but only significantly for the $\alpha$-Est locus. The consideration of male contribution (product of male catkin abundance and flowering frequency) did not really improve the expected values. The consideration of both traits reduced the $\chi^{2}$ values, except for locus $M d h-1$. The pollen frequencies were not those expected according to the male reproductive contribution of the clones. The effects were different according to the considered locus.

\section{DISCUSSION}

\section{Use of rare alleles}

Isozymes are generally considered as neutral markers and thus suitable for phylogenetic studies. Our analysis was focused on 3 rare alleles; 2 showed a significant disadvantage during female transmission. In $P$ sylvestris Müller-Starck (1982a) observed an asymmetrical contribution of male and female gametes to the offspring at a Got locus. Adams et al (1990) did not record any significant segregation deviation in Douglas fir megagametophytes at Got-1 or Mdh-3 loci. None of the rare alleles appeared to be neutral markers. Rare alleles are probably sometimes unfavourable; some clones bearing rare alleles were not studied because of their poor flowering. Busch and Smouse (1992) also considered that most rare alleles are disadvantageous. The disadvantage of a rare allele is not nec-

Table VII. Test of similarity $\left(\chi^{2}\right)$ of observed and expected allele frequencies at 5 polymorphic loci in pollen gametes of the commercial seed crop.

\begin{tabular}{|c|c|c|c|c|}
\hline Locus & $\begin{array}{l}\text { Theoretical } \\
\text { seed orchard }\end{array}$ & $\begin{array}{c}\text { Actual number } \\
\text { of ramets }\end{array}$ & $\begin{array}{l}\text { Male flower } \\
\text { contribution }\end{array}$ & $\begin{array}{l}\text { Ramet number } \\
\text { male flower contr }\end{array}$ \\
\hline$\alpha-E s t$ & $16.7^{\star \star}$ & 10.5 & $17.3^{\star \star}$ & $12.0^{*}$ \\
\hline G6pdh & 9.4 & 10.4 & 8.9 & 8.8 \\
\hline Lap-1 & $24.2^{\star \star *}$ & $22.8^{\star \star \star \star}$ & $20.8^{\star \star *}$ & $19.1^{\star * *}$ \\
\hline$M d h-1$ & $38.1^{\star \star \star \star}$ & $43.1^{* * \star}$ & $34.6^{\star \star *}$ & $38.1^{* \star \star}$ \\
\hline$M d h-3$ & 1.4 & 3.2 & 1.7 & 0.5 \\
\hline
\end{tabular}

Expected frequencies were calculated on the basis of 4 different mating assumptions: random mating among clones (theoretical seed orchard); random mating after weighting the numbers of their ramets (actual number of ramets); the fertility of clones (male flower contribution); and both fertility and real number of ramets (ramet number and male flower contribution). Significant deviation at the $0.05^{*}, 0.01^{\star \star}$ and $0.001^{\star \star \star}$ levels respectively (degree of freedom: $6,5,3$, 2 and 2 respectively to the 5 loci studied). 
essarily intrinsic, it might result from a genetic linkage to an adaptation gene. Consequently, the selfing rate cannot be deduced accurately from transmission of rare alleles without precaution. A multilocus approach based on common alleles has been recommended (Shaw and Allard, 1979, 1982).

The characterisation and identification of the commercial seedlot from an orchard is useful for verifying plantations with controlled plant material. The introduction of clones marked by rare alleles in the seed orchard may be a way of identifying a seedlot as suggested by $P$ Baradat (personal communication). The disadvantage of some rare alleles makes this method difficult. The identification of the seed by rare alleles would be possible if the marked seed is introduced and mixed into the collected seed from the orchard.

\section{Mating system}

Part of the pollen flow in various seed orchards was not accounted for and often came from surrounding stands. This contamination might represent the main pollen flow in some cases (Fast et al, 1986; Adams and Birkes, 1991). In the Bout seed orchard a significant contamination from surrounding stands did not exist, since the other seed orchard was on a small area (2.5 ha) at about $1 \mathrm{~km}$ to the east (dominant wind from west). However an endogenous contamination was caused by the replacement of the scions by rootstocks after a rejection of the graft, which were not removed. The effect of this contamination on the seed quality should be minimised with mother trees selected for high general combining abilities.

A mixed-mating model, including selfand cross-fertilisation probabilities only, has often been applied in forest trees (MüllerStarck, 1982b; Ritland and El-Kassaby,
1985). The selfing rates estimated in this paper were similar using mixed-mating model or rare alleles. Nevertheless, rare alleles can only be used when they did not show any segregation distortion especially in pollen transmission. The proportion of selfing, ie the proportion of selfed embryos among open-pollinated viable embryos, has mostly been assessed in the analyses of mating system. Selfing proportion varies according to the segment considered within the tree: orientation and height within a single tree influence mating system (El-Kassaby et al, 1986; Omi and Adams, 1986) and from tree to tree (Erickson and Adams, 1990). Reproductive phenology was a major component determining selfing (Erickson and Adams, 1989). El-Kassaby et al (1988) noticed a higher outcrossing rate $(0.968)$ in the intermediate phenological class than in the late one (0.893). In France, clones were selected for climate adaptation, mainly for late bud burst, which is correlated with reproductive phenology. Thus in the Bout seed orchard, the flowering period was shorter (about 1 week) than in that studied by ElKassaby et al (1988); the possible effect of reproductive phenology should be less marked and probably negligible in Bout orchard. In another French Douglas fir seed orchard, early- or late-flowering ramets had the same outcrossing rates (Burczyk and Prat, unpublished results). When reproductive phenological variation is reduced, its effects on mating system can become nonsignificant. However, the competition between self- and outcrossed pollen plays an important role (El-Kassaby and Davidson, 1991). Selfing is not the most critical deviation from panmixia in a clonal seed orchard: selfed plants have a reduced competitiveness and most of them should be easily suppressed in the nursery because of their disadvantage.

Thus the selfing rate observed in the Bout seed orchard was less than $5 \%$ and low enough not to affect the genetic quality 
of the seed produced. Fixation index in commercial seedlot was higher than that expected from the selfing rate, which might result from an underestimation of selfing because the chosen ramet exhibited particularly low selfing. A variation of selfing rate in a seed orchard has already been recorded (Omi and Adams, 1986; Erickson and Adams, 1990). Selfing was not the only possible deviation to the Hardy-Weinberg equilibrium; crossing between neighbour trees, correlated matings, or effects of phenology are often reported as a limitation of random mating (El-Kassaby et al, 1988; Ritland, 1988; Copes and Sniezko, 1991; Adams et al, 1992). In the Bout seed orchard, crossing between close trees seemed to be the main factor influencing homozygosity level of seed crop (Prat, 1995). The differentiation of clone subpopulations in the seed orchard according to their original French stands suggested that French stands came from different provenances that were mixed in the seed orchard.

As a conclusion of this study, it can be assumed that selfing rate was low in the Bout seed orchard and should not affect genetic quality of commercial crop. Nevertheless commercial seedlot exhibited a higher fixation index than parent trees and its increase was not solely due to selfing rate. Further studies are required to explain the heterozygosity level of progeny.

\section{ACKNOWLEDGMENTS}

We would like to thank JC Bastien and B Roman-Amat for their great interest in this study and the research material they provided, and also $E$ Teissier Du Cros for critical reading of the manuscript. This research was supported by the Groupement d'intérêt scientifique - création, évaluation et diffusion de variétés forestières améliorées, grant No 87.G.0315 from ministère de la Recherche et de l'Enseignement supérieur.

\section{REFERENCES}

Adams WT, Birkes DD (1991) Estimating mating patterns in forest tree populations. In: Biochemical Markers in the Population Genetics of Forest Trees (S Fineschi, ME Malvolti, F Cannata, $\mathrm{HH}$ Hattemer, eds), SPB Academic Publsh bv, The Hague, The Netherlands, 157-172

Adams WT, Neale DB, Doerksen AH, Smith DB (1990) Inheritance and linkage of isozyme variants from seed and vegetative bud tissues in coastal Douglas fir (Pseudotsuga menziesii var menziesii (Mirb) Franco). Silvae Genet 39, 153-167

Adams WT, Griffin AR, Moran GF (1992) Using paternity analysis to measure effective pollen dispersal in plant population. Am Nat 140, 762-780

Bastien JC, Roman-Amat B (1990) Predicting Douglas fir (Pseudotsuga menziesii (Mirb) Franco) volume at age 15 with early traits. Silvae Genet 39, 29-35

Bastien JC, Roman-Amat B, Michaud D (1986) Douglas. In: Amélioration Génétique des Arbres Forestiers. Rev Forest Fr 38, 113-120

Bush RM, Smouse PE (1992) Evidence for the adaptative significance of allozymes in forest trees. In: Population Genetics of Forest Trees (WT Adams, SH Strauss, DL Copes, AR Griffin, eds). Kluwer Academic Publsh, Dordrecht, The Netherlands, 179-196

Christophe C, Birot $Y$ (1983) Genetic structure and expected genetic gains from multitrait selection in wild populations of Douglas fir and stika spruce. II. Practical application of index selection on several populations. Silvae Genet 32, 173-181

Conkle MT, Hodgskiss PD, Nunnally LB, Hunter SC (1982) Starch gel electrophoresis of conifer seeds: a laboratory manual. USDA Forest Service, Pacific SW Range Experiment Station, USA, Gen Tech Rep PSW-64

Copes DL, Sniezko RA (1991) The influence of floral bud phenology on the potential mating system of a wind-pollinated Douglas fir orchard. Can J For Res 21, 813-820

El-Kassaby YA, Davidson R (1991) Impact of pollination environment manipulation on the apparent outcrossing rate in a Douglas fir seed orchard. Heredity $66,55-59$

El-Kassaby YA, Ritland K (1986) The relation of outcrossing and contamination to reproductive phenology and supplemental mass pollination in a Douglas fir seed orchard. Silvae Genet 35, 240-244

El-Kassaby YA, Parkinson J, Devitt WJB (1986) The effect of crown segment on the mating system in a Douglas fir (Pseudotsuga menziesii (Mirb) Franco) seed orchard. Silvae Genet 35, 149-155

El-Kassaby YA, Ritland K, Fashler AMK, Devitt WJB (1988) The role of reproductive phenology upon the mating system of a Douglas fir seed orchard. Sivae Genet 37, 76-82 
Erickson VJ, Adams WT (1989) Mating success in a coastal Douglas fir seed orchard as affected by distance and floral phenology. Can J For Res 19, 12481255

Erickson VJ, Adams WT (1990) Mating system variation among individual ramets in a Douglas fir seed orchard. Can J For Res 20, 1672-1675

Fast W, Dancik BP, Bower RC (1986) Mating system and pollen contamination in a Douglas fir clone bank. Can J For Res 16, 1314-1319

Müller-Starck G (1982a) Sexualiy asymmetric fertility selection and partial self-fertilization. 2. Clonal gametic contributions to the offsprings of a Scots pine seed orchard. Silvae Fennica 16, 99-106

Müller-Starck G (1982b) Reproductive systems in conifer seed orchards. I. Mating probabilities in a seed orchard of Pinus sylvestris L. Silvae Genet 31, 188-197

Omi SK, Adams WT (1986) Variation in seed set and proportions of outcrossed progeny with clones, crown position and top pruning in a Douglas fir seed orchard. Can J For Res 16, 502-507

Prat D (1995) Mating system in a clonal Douglas fir ( $P$ seutotsuga menziesii (Mirb) Franco) seed orchard. II. Effective pollen dispersal. Ann Sci For 52, 213-222

Prat D, Caquelard T (1991) Estimation of selfing rate in a Douglas fir seed orchard by means of rare alleles. In: Biochemical Markers in the Population Genetics of Forest Trees (S Fineschi, ME Malvolti, F Cannata, $\mathrm{HH}$ Hattemer, eds). SPB Academic Publsh bv, The Hague, The Netherlands, 235-236
Ritland K (1986) Joint maximum likelihood estimation of genetics and mating structure using open-pollinated progenies. Biometrics 42, 25-43

Ritland K (1988) The genetic-mating structure of subdivised populations. II. Correlated mating models. Theor Pop Biol 34, 320-346

Ritland K, El-Kassaby YA (1985) The nature of inbreeding in a seed orchard of Douglas fir as shown by an efficient multilocus model. Theor App/ Genet 71 , 375-384

Shaw DV, Allard RW (1979) Analysis of mating system parameters and population structure in Douglas fir using single locus and multilocus methods. USDA Forest Service, Pacific SW Range Experiment Station, USA, Gen Tech Rep PSW-48, 1822

Shaw DV, Allard RW (†982) Estimation of outcrossing rates in Douglas fir using isozyme markers. Theor App/ Genet 62, 113-120

Sorensen FC (1982) Inbreeding depression in height, height growth, and survival of Douglas fir, ponderosa pine, and noble fir to 10 years of age. For Sci 28 , 283-292

Sorensen FC, White TL (1988) Effect of natural inbreeding on variance structure in tests of wind-pollination Douglas fir progenies. For Sci 34, 102-118

Wright $S$ (1965) The interpretation of population structure by $F$-statistics with special regard to systems of mating. Evolution 19, 395-420 